SYSTEMS CONCEPTS IN ACTION 



\title{
SYSTEMS CONCEPTS
} IN ACTION

\section{A Practitioner's Toolkit}

\author{
BOB WILLIAMS AND \\ RICHARD HUMMELBRUNNER
}

STANFORD BUSINESS BOOKS 


\section{Stanford University Press}

Stanford, California

English translation and new material @ 2011 by the Board of Trustees of the Leland Stanford Junior University. All rights reserved.

Copyright $\odot 2009$ Rosenberger Fachverlag for the original version. All Rights Reserved. This translation is published by arrangement with the Publisher.

No part of this book may be reproduced or transmitted in any form or by any means, electronic or mechanical, including photocopying and recording, or in any information storage or retrieval system without the prior written permission of Stanford University Press.

Special discounts for bulk quantities of Stanford Business Books are available to corporations, professional associations, and other organizations. For details and discount information, contact the special sales department of Stanford University Press. Tel: (650) 736-1782, Fax: (650) 736-1784

Printed in the United States of America on acid-free, archival-quality paper

Library of Congress Cataloging-in-Publication Data

Williams, Bob, 1951-

Systems concepts in action : a practitioner's toolkit / Bob Williams and Richard Hummelbrunner.

p. $\mathrm{cm}$.

Includes bibliographical references and index.

ISBN 978-0-8047-7062-0 (cloth : alk. paper)-ISBN 978-0-8047-7063-7 (pbk. : alk. paper)

1. System theory. 2. Management science. I. Hummelbrunner, Richard. II. Title.

Q295.W53 2010

$003-\mathrm{dc} 22$ 